金融トレーダーの男性ホルモン值が景気を左右する?

\title{
The testosterone of trading
}

\section{ホルモン值の変動が金融市場での成功に影響しているのかもしれない。}

doi:10.1038/news.2008.753/14 April 2008

Geoff Brumfiel

本や映画では、金融トレーダーは、マッ チョなギャンブラーとして描かれること が多い。今回、そのようなイメージを 裏づける科学的証拠が得られたようで ある。2 人の研究者が、ロンドン市場 で働くトレーダーたちのテストステロン 值と運用益に関連性があることを見つ けたのである。

トレーダーから神経科学者に転身 した英国ケンブリッジ大学のJohn Coatesは、金融市場で働いていたこ ろの経験を基にして研究を始めた。証 券取引の立ち会い所にいるトレーダー たちは、大きな利益を上げたときには 激しく興奮し、損失を被ったときには がっくりと落ち込んだ。「それは、まる で典型的な躁うつの行動でした」と彼 はいう。

Coatesの目には、少数ながらいる 女性トレーダーたちは「男性に比べて 影響を受けていない」ように映った。 そこで彼は、ホルモン、なかでも典型 的な男性ホルモンであるテストステロ ンが男性トレーダーの行動にかかわっ ているのではないかと、うすうす感じ始 めたのだという。

これをはっきりさせるため、Coates はケンブリッジ大学の同僚であるJoe Herbertと、ロンドン金融市場で連続 8 営業日の間、17 人の男性トレーダー を追跡調査した。2人は、1 日の取り 引きが始まる前と終わった後に、トレー ダーたちから唾液サンプルを採取した。 そして、そこに含まれるテストステロン と、先行き不安な状態に置かれると産 生されるコルチゾールの 2 種類のホル モン值を解析した。

\section{因果関係か相関関係か ?}

その結果はCoatesによると、 Proceedings of the National Academy of Sciences 誌上で発表されたように明
らかなものだった 1。「トレーダーたち は、テストステロン值が平均以上の日 には、平均以上の利益を上げていまし た」。17人のうち 14 人のトレーダー では、朝のテストステロン值が高かっ た日に、より多くの利益を出していた。

トレーダー業で好成績を上げること に、テストステロンが関係しているの だろうか。Coates はそうだと考えてい る。しかしHerbertは、今回の結果は、 テストステロンがリスクを冒す行動を推 進していることを実証するには十分では ないと、慎重な態度をとっている。「相 関関係はあるが、因果関係があるとま ではいえない」という。

一方コルチゾール值は、取り引きの 成功や失敗とは相関関係がないようで ある。このホルモンの值はむしろ、市 場の相場が乱高下するのに伴って上昇 するようすがみられた。相場の乱高下は、 トレーダーたちの生活にいっそうのスト レスをもたらしている可能性がある。

\section{ホルモンの「高値」}

今回の知見は 1 つの興味深い可能性を 示すものだ、とCoatesはいう。すな わち、金融市場の抱える不合理性がホ ルモンによって増進されている可能性で ある。市場の「バブル」で目を見張る ほどつり上がった高值は、トレーダーた ちのテストステロン值上昇によってさら につり上がる可能性があり、また一方 で、相場の暴落と売り急ぎはコルチゾー ルによってさらに状況が悪化する可能 性があると、Coates は考えている。

解析対象の標本サイズが小さいせい で、そうした憶測が幅を利かせてしまう のだ、とゲント大学 (ベルギー) の生 物社会学者であるHans Vermeersch は苦言を呈している。Vermeersch は既に、十代の若者でテストステロン と危険を冒す行動の間に関連性があ

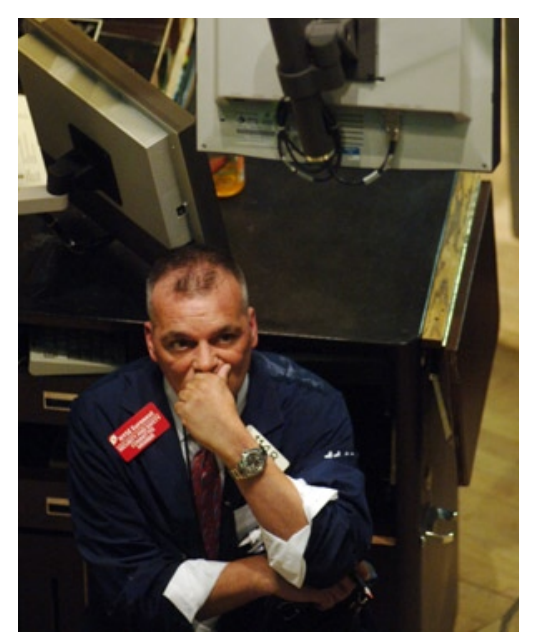

テストステロンとコルチゾールは、さまざまな ストレス誘発要因を反映して值が変動してい るのかもしれない。

ることを自身の研究で明らかにしてお り、性的活動や食習慣、さらには朝の 通勤といったほかの多くの要因がトレー ダーのホルモン值にかかわっているの ではないかと話す。そしてCoatesた ちの論文は、市場も同じようにホルモ ン值に影響を及ぼしていることを示す ものだと彼はいう。

「今回の結果は私にとってはさほど 驚くものではない」と、ロンドンで金 利トレーダーをしているBenedict Stoddart は話す。「利益を上げたり損 失を出したりするときには、感情的な 反応が伴います」。しかし、だからといっ てトレーダーをテストステロン全開の一 匹オオカミだとする世間の見方が正し いわけではない、と彼は付け加えた。 実際、大部分の雇用主は、たとえホル モン值が「乱高下」しても沈着冷静で あり続けようとするトレーダーを雇いた いと考えているはずである。

1. Coates, J. M. \& Herbert, J. Proc. Natl Acad. Sci. USA 105, 6167-6172(2008). 